\title{
PHYSICAL ACTIVITY AND BODY COMPOSITION OF 5 TO 7 YEARS OLD CHILDREN
}

\author{
Ján Junger, Andrea Palanská, Pavol Čech
}

\author{
University of Presov, Slovakia
}

Junger J., Palanska A., Čech P., (2014) Physical activity and body composition of 5 to 7 years old children. Health Problems of Civilization 3 (8), p. 12-19.

\begin{abstract}
Summary: Current exercise prescription and physical activity guidelines recommend preschool children to perform at least 60 minutes of moderate to vigorous structured physical activity and at least 60 minutes of unstructured physical activity every day. The purpose of this study was to extend knowledge about the volume of physical activity in 5- to 7-year-old children in relation to their body composition. Also, we recorded the course of growth changes and physical activity levels in 6 -year-old children in the previous half century. The sample consisted of 69 pre-school age children ( $5-7$ years) attending selected kindergartens located in the area of Presov self-governing region. Of 69 children, 36 were girls and 33 were boys. The volume and intensity of physical activity performed by children during their stay in kindergartens was measured using heart rate monitoring system POLAR Team ${ }^{2}$ Pro. Body composition was assessed using direct segmental multi-frequency bioelectric impedance analysis (DSM-BIA) device InBody 230. Parameters of somatic development corresponding with the secular trend are disproportionate to children's physical activity, which is considered to be an irreplaceable factor underlying health of children. However, the physical activity levels of children are decreasing. The volume of physical activity does not meet the minimum standard recommended by NASPE (Prokopec et al. 1986) and average intensity of physical activity expressed by heart rate does not reach the medium intensity zone.
\end{abstract}

Key words: preschool child, body composition, physical activity, obesity, norms

\section{Introduction}

One of the most beneficial values and primary factors determining quality of life is state of health. As no one can take it for granted, each of us should take care of their health throughout their entire lives. Therefore, educating and leading children towards pursuing a healthy lifestyle during initial stages of ontogeny is the most important and the most effective purpose in life.

Knowledge about lives of our predecessors has confirmed that physical activity has been dominant in promoting health of people throughout entire phylogeny (Junger 2010). Performing regular physical activity (PA) in childhood increases levels of future physical activity in adulthood (Kraut 2003, Malina 2004). Positive effect of physical activity on health is generally known and has been supported by scientific evidence. Moreover, regular physical activity increases physical fitness, improves body weight and promotes overall health depending on the optimal physical activity level (LaMonte 2009). According to physical activity guidelines for children preschoolers should accumulate at least 60 minutes daily of structured physical activity and should engage in at least 60 minutes of unstructured physical activity (National association for sport and physical education). Children should perform moderate to high intensity physical activity, which corresponds to $130 \mathrm{bpm}$, or more than 3 METs. Corbin, Pangrazi (Corbin 1996) and Pangrazi, Corbin \& Welk (Pangrazi 1996) have reported that children should perform at least 30 to 60 minutes of moderate to vigorous physical activity during their school time and leisure time. It should be noted that almost 30 years ago, to stimulate the natural development of their organisms children were supposed to engage in physical activity during $60 \%$ of time being awake, which amounts to approximately 6 hours (Kučera 1991), at least 2.5 to 3 hours of physical activity in the average zone for the stimulation of cardiovascular functions equaling to $150 \%$ of resting values (Kučera 1985,1991 ).

Despite decrease in the recommended physical activity levels, several studies have reported that preschoolers do not engage in sufficient physical activity. According to Tucker (Tucker 2008) only 54\% of participants throughout the studies analyzed achieved current NASPE recommendations suggesting a minimum of 60 minutes of physical activity per day. The current trend in low physical activity levels is not being eliminated accordingly. Over the

Address for correspondence: Ján Junger, University of Prešov, 17. novembra 15, 08001 PREŠOV, e-mail: jungerj0@unipo.sk, phone: 421-51-7470502

Tables: 3, Figures: 3, References: 25, Full text PDF www.hpc.edu.pl Copyright @ Pope John Paul II State School of Higher Education in Biała Podlaska, Sidorska 95/97, 21-500 Biała Podlaska Indexation: Index Copernicus, Database AGRO, ProQuest, Polish Ministry of Science and Higher Education. This is an open-access article distributed under the terms of the Creative Commons Attribution Non-commercial License (http://creativecommons.org/licenses/by-nc/3.0), which permits use, distribution, and reproduction in any medium, provided the original work is properly cited, the use is non-commercial and is otherwise in compliance with the license. 
past few years, pediatricians have revealed that children suffer with diseases present in adults such as hypertension, cardiovascular and respiratory diseases and diabetes. These diseases share overweight as an identical risk factor. Compared to their age-matched counterparts from the 1960s to 1980s, present children are taller (boys by $1.4 \mathrm{~cm}$ and girls by $1.2 \mathrm{~cm}$ ) and heavier (Prokopec 1986, Blaha 1990, Blaha Vignerova 1998, Junger 2010). As reported by Canning, Courage, \& Frizzell (Canning et al. 2004) and WHO (World Health Organization) as much as 22 million children under the age of 5 are obese. In Slovakia, $6 \%$ of children are overweight and $12 \%$ are obese (Béderová 2003). Chronic and non-infectious diseases including overweight and obesity cause 63\% of deaths worldwide, which amounts to 36 million deaths per year. The number of deaths in childhood and at productive age was 9 million (World Health Organization). Therefore, engaging in physical activity as a beneficial factor (National association for sport and physical education) should be emphasized in terms of obesity prevention (Hainer 2004).

\section{Objectives}

The purpose of this study was to extend knowledge about the volume of physical activity in 5- to 7-year-old children in relation to their body composition. Also, we recorded the course of growth changes and physical activity levels in 6-year-old children in the previous half century.

\section{Material \& methods}

\section{Participants}

A non-randomized cross-sectional study was used to describe body composition and physical activity of preschool children and to evaluate gender differences. The sample consisted of 69 preschool age children ( 5 - 7 years) attending selected kindergartens located in the area of Prešov self-governing region. Of 69 children, 36 were girls and 33 were boys. Mean age, body height, body weight and body mass index at the time of measurement was $5.9 \pm$ 0.5 years, $116.1 \pm 6.0 \mathrm{~cm}$, body weight $21.3 \pm 4.0 \mathrm{~kg}$ and $15.7 \pm 2.0 \mathrm{~kg} \cdot \mathrm{m}^{-2}$, respectively. At the time of testing, children did not suffer with any metabolic or motor disorders that could have effect on test results.

\section{Measures and Procedures}

The volume and intensity of physical activity performed by children during their stay in kindergartens was measured using heart rate monitoring system POLAR Team ${ }^{2}$ Pro (Polar Electro; Kempele, Finland). This system allows for direct and real-time heart rate monitoring of several individuals at the same time. Data are transmitted wirelessly to a receiver which is connected with a standard laptop with relevant software. The results of this study are based on data of 40 randomly selected children due to objective reasons connected with conducting the research. During the entire time spent in kindergartens, children wore heart rate monitors to determine their average heart rate. Also, we determined the average heart rate during physical activity performed in the kindergarten. The intensity of physical activity was set at $135 \mathrm{bpm}$ (3 METs), which corresponds with at least medium intensity exercise monitored according to NASPE. In total, we monitored 40 days during summer and fall under standard weather conditions typical for these seasons of year. Average daily temperatures ranged from 17 to $25^{\circ} \mathrm{C}$. Children had a chest strap attached to their chests and wore it for approximately 8 hours per day. The volume of their physical activity during their leisure time was determined according to time records filled in by their parents during the weeks children were monitored.

Before analysis of body composition, the participants took part in the basic measurement of anthropometric parameters. Body height was measured using a portable stadiometer (SECA 217, Hamburg, Germany) to the nearest $0.1 \mathrm{~cm}$. Body weight was measured to the nearest $0.1 \mathrm{~kg}$. Body composition was assessed using direct segmental multi-frequency bioelectric impedance analysis (DSM-BIA) device InBody 230 (Biospace Co., Ltd.; Seoul, Korea). In Body 230 device uses 8-point electrodes and uses the principle of 10 impedance measurements by using two different frequencies $20 \mathrm{kHz}$ and $100 \mathrm{kHz}$ at each 5 body segments. Measurement history was retrieved using database management software Lookin'Body version 3.0 (Biospace Co., Ltd.; Seoul, Korea). To compute indirectly measurable parameters we used prediction equations available for particular age categories. Body composition was measured using the bioimpedance method under standard conditions described in the BIA guidelines (Kyle 2004). The room temperature was kept between 20 and $24^{\circ} \mathrm{C}$ to prevent undesirable changes in body water composition. Among parameters measured were skeletal muscle mass (SMM), absolute value of fat free mass (FFM), percentage of body fat mass (PBF), waist to hip ratio (WHR), estimated value of basal metabolic rate (BMR) and parameters of nutrition in the protein mass (PM) and mineral mass (MM). 


\section{Statistical Analysis}

Collected data were processed statistically and effect size analysis was conducted. Descriptive statistical characteristics of data were arithmetic mean as measure of central tendency and standard deviation as a measure of variability. The statistical significance of gender differences in parameters of the participants' body composition and physical activity parameters was determined using t-test for independent samples. The equality of variances was assessed using Levene's test (F-test). To reject the null hypothesis and to accept alternative hypothesis, level of significance was set at $p<0.05$.

Practical significance by gender was assessed using coefficient "Eta square" $\left(\eta^{2}\right)$, which determines the contribution of the contribution of an effect. The effect size of the factor was assessed according to Cohen (Cohen 1988) $\eta^{2}<0.06$ (small), $0.06 \leq r<0.14$ (medium), $r \geq 0.14$ (large).

The association between selected measures of body composition and physical activity levels irrespective of gender of preschool children was determined using Spearman's correlation analysis, which was selected due to low sample size $(n=40)$. Statistical analysis was carried out using IBM SPSS Statistics 20 software.

Parents of participants received a verbal description of the study procedures before testing and completed a written informed consent that was approved by the ethical committee of Presov University in Presov. Measurements were performed according to the ethical standards of the Helsinki Declaration.

\section{Results}

One of the purposes of the study was to assess body composition of preschool children. Descriptive and statistical data on body composition according to gender are presented in Table 1. There were no statistically or practically significant differences between genders for age, body height, body weight and BMI. The greatest differences, although insignificant, were found for body height and body weight. Boys were taller by $2.3 \mathrm{~cm}$ and heavier by 0.9 $\mathrm{kg}$ than girls. There were minimal differences with regard to differences between children relative to age and BMI. Similarly, no statistically significant $(p>0.05)$ or practically significant $\left(\eta^{2}<0.06\right)$ differences were found for body composition parameters. The difference between genders for percentage body fat (PBF) was $2.2 \%$. Significant differences between boys and girls with medium size effect was found for skeletal muscle mass (SMM), fat-free mass (FFM) and basal metabolic rate (BMR). Higher values in body composition parameters were found for boys. Significant gender differences confirmed by large size effect were found for parameters indicating nutritional status of children, i.e. protein mass $\left(\mathrm{t}_{(67)}=2.571, p=0.012, \eta^{2}=0.90\right)$ and mineral mass $\left(\mathrm{t}_{(67)}=2.559, p=0.013, \eta^{2}=0.89\right)$. Values for these body composition parameters were higher for boys than girls.

In addition to body composition assessment, we analyzed physical activity levels in both the kindergarten setting and the home setting. With respect to parameters used to assess physical activity levels, significant differences between boys and girls were found for average heart rate during physical activity $\left(\mathrm{t}_{(38)}=2.459, p=0.019, \eta^{2}=\right.$ $0.137)$ and the volume of physical activity performed in the kindergarten $\left(\mathrm{t}_{(38)}=2.541, p=0.015, \eta^{2}=0.145\right)$. Boys compared to girls had higher average heart rate and physical activity level. There were no statistically significant $(p>0.05)$ and practically significant gender differences $\left(\eta^{2}<0.06\right)$ for $\mathrm{HR}_{\mathrm{A}^{\prime}} \mathrm{PA}_{\mathrm{H}}$ a $\mathrm{PA}_{\text {sum }}$ (Table 2$)$.

The assessment of the relationship between physical activity levels and body composition of children showed only weak or very weak power of relation in most parameters (see Table 3). However, as seen in Figure 1 a moderate power of relation $\left(\mathrm{r}_{\mathrm{s}}=0.526, p<0.05\right)$ was found between waist-to-hip ratio (WHR) and physical activity performed in the kindergarten $\left(\mathrm{PA}_{\mathrm{H}}\right)$.

The associations between body composition and physical activity levels may be explained by a variety of factors. Such degree of association can be attributed to low sample size or to a large extent to data homogeneity. With respect to obesity (not found) classified according to BMI, or overweight (found in one child) data on body composition were homogeneous across the sample. This may indicate that somatic development at this age is determined predominantly by endogenous factors and not difference between lifestyles.

\section{Discussion}

Concerning anthropological parameters assessed irrespective of gender, average body height of children (BH) was $116.1 \mathrm{~cm}(\mathrm{SD}=6.0 \mathrm{~cm})$ and average body weight $(\mathrm{BW})$ was $21.3 \mathrm{~kg}$ (SD = $4.0 \mathrm{~kg})$. According to WHO [24] norms for this age period, 7 children were found to have higher body weight and three children had lower body weight than standard body weight.

Mean body mass index value (BMI) was $15.7 \mathrm{~kg} \cdot \mathrm{m}^{-2}\left(\mathrm{SD}=2.0 \mathrm{~kg} \cdot \mathrm{m}^{-2}\right)$. According to obesity classification based on BMI, six children were overweight and one child was underweight. What may be regarded as positive is the fact that no child was obese according to their BMI. However, this does not hold true for older children (Béderová 2003). 
Mean skeletal mass (SMM) was $8.2 \mathrm{~kg}(\mathrm{SD}=1.5 \mathrm{~kg}$ ) and mean fat-free mass was $17.3 \mathrm{~kg}$ (SD = $2.4 \mathrm{~kg})$. Despite this, mean percentage body fat (PBF) was $18.2 \%(\mathrm{SD}=6.3 \%)$. Alarming with respect to WHO standards is the fact that percentage muscle mass was lower than reference WHO value in 21 children. Contrary to this, 19 children were found to have percentage body fat higher than reference norms.

Regarding nutritional status of children, mean protein mass (PM) was $3.4 \mathrm{~kg}(\mathrm{SD}=0.5 \mathrm{~kg}$ ) and mean mineral mass (MM) was $1.2 \mathrm{~kg}(\mathrm{SD}=0.2 \mathrm{~kg}$ ). In total, 13 children had deficient volume of protein mass, which may be attributed to lower degree of muscularity. Mean waist-to-hip ratio (WHR) indicative of abdominal obesity was 0.75 (SD = 0.04).

Monitoring lifestyle of children showed that average volume of daily physical activity (PA) performed in the kindergarten was 30 minutes ( $S D=20.11 \mathrm{~min}$ ). Mean volume of physical activity performed out of kindergartens during weekdays was approximately 72 minutes per day $(\mathrm{SD}=28.06 \mathrm{~min})$. Total volume of daily physical activity was 102 minutes ( $\mathrm{SD}=3.7 \mathrm{~min}$ ). This shows that children engaged in 12 minutes less physical activity according to minimum daily physical activity level recommended by NASPE.

The response of child organism to physical activities was monitored by heart rate recorded during children's stay in kindergartens. The average heart rate of children was $119 \mathrm{bpm}(\mathrm{SD}=7 \mathrm{bpm})$. We decided to monitor especially heart rate of children during structured physical activities, which showed that average heart rate was 131 bpm (SD = 10 bpm). Compared to findings reported by Kučera (Kučera 1991) who monitored heart rate of preschool children using telemetry, average heart rate of children in our study is lower by $42 \mathrm{bpm}$. According to NASPE guidelines accepted in both Czech Republic and Slovak Republic, a child should engage in at least 120 minutes of moderate to vigorous physical activity. The zone of medium intensity physical activity equivalent to 3-6 METs ranges from $135 \mathrm{bpm}$ to $191 \mathrm{bpm}$. With respect to the heart rate range mentioned above, children in our study rarely performed physical activity at a required level of medium intensity.

Our results have revealed interesting findings. We have found a generally observed manifestation of the secular trend present in most developing countries. Children are getting taller and heavier at the same time, which has been confirmed by National Anthropometric Survey conducted nationwide in Slovak Republic since 1951 (Figure 2). On the other hand, we find it alarming and detrimental to the health of children that data do not correspond with the volume and intensity of physical activity, which is still considered to be an irreplaceable factor underlying their healthy development (Figure 3). Therefore, children tend to be taller and heavier, which makes them quit exercising.

Table 1. Comparison of body composition indicators of participants with respect to their gender

\begin{tabular}{|c|c|c|c|c|c|c|c|c|}
\hline \multirow{2}{*}{\multicolumn{2}{|c|}{ Variables }} & \multirow{3}{*}{$\begin{array}{c}\text { Mean } \\
5.9 \\
\end{array}$} & \multirow{3}{*}{$\begin{array}{c}\begin{array}{c}\text { Standard } \\
\text { deviation }\end{array} \\
0.43 \\
\end{array}$} & \multicolumn{2}{|c|}{ Levene's Test for Equality of Variances } & \multicolumn{2}{|c|}{ T-test for Equality of Means } & \multirow{4}{*}{$\begin{array}{c}\eta^{2} \\
0.03 \\
\text { (small) }\end{array}$} \\
\hline & & & & $\mathrm{F}$ & $\mathrm{p}$ & $\mathrm{t}$ & $\mathrm{p}$ & \\
\hline$\Delta$ ar (uoprc) & G & & & \multirow{2}{*}{1.064} & \multirow{2}{*}{0.306} & \multirow{2}{*}{-0.466} & \multirow{2}{*}{0.643} & \\
\hline Age (years) & B & 5.8 & 0.57 & & & & & \\
\hline \multirow{2}{*}{$\mathrm{BH}(\mathrm{cm})$} & G & 115.0 & 5.81 & \multirow{2}{*}{0.147} & \multirow{2}{*}{0.703} & \multirow{2}{*}{1.579} & \multirow{2}{*}{0.119} & 0.036 \\
\hline & $\mathrm{B}$ & 117.3 & 6.07 & & & & & (small) \\
\hline \multirow{2}{*}{ BW (kg) } & $\mathrm{G}$ & 20.9 & 4.38 & \multirow{2}{*}{1.791} & \multirow{2}{*}{0.185} & \multirow{2}{*}{0.988} & \multirow{2}{*}{0.327} & 0.014 \\
\hline & $\mathrm{B}$ & 21.8 & 3.46 & & & & & (small) \\
\hline \multirow{2}{*}{ BMI $\left(\mathrm{kg} \mathrm{m}^{-2}\right)$} & G & 15.7 & 2.35 & \multirow{2}{*}{3.893} & \multirow{2}{*}{0.053} & \multirow{2}{*}{0.216} & \multirow{2}{*}{0.830} & 0.001 \\
\hline & $\mathrm{B}$ & 15.8 & 1.42 & & & & & (small) \\
\hline \multirow{2}{*}{ SMM (kg) } & G & 7.8 & 1.40 & \multirow{2}{*}{0.149} & \multirow{2}{*}{0.700} & \multirow{2}{*}{2.437} & \multirow{2}{*}{0.017} & 0.081 \\
\hline & $\mathrm{B}$ & 8.6 & 1.49 & & & & & (medium) \\
\hline \multirow{2}{*}{ FFM (kg) } & G & 16.6 & 2.29 & \multirow{2}{*}{0.288} & \multirow{2}{*}{0.593} & 2555 & 0013 & 0.089 \\
\hline & $\mathrm{B}$ & 17.8 & 2.32 & & & 2.555 & 0.013 & (medium) \\
\hline $\mathrm{PBF}(\%)$ & G & 19.3 & 7.04 & 1234 & 0.271 & -1499 & 0.139 & 0.032 \\
\hline & $\mathrm{B}$ & 17.1 & 5.25 & & 0.271 & -1.499 & 0.159 & (small) \\
\hline WHR & G & 0.75 & 0.04 & 0142 & 0708 & -0731 & 0467 & 0.008 \\
\hline WHK & $\mathrm{B}$ & 0.74 & 0.04 & 0.142 & 0.108 & -0.131 & $0.46 /$ & (small) \\
\hline BMR (kcal) & G & 728.1 & 49.4 & 0.294 & 0.589 & 2541 & 0.013 & 0.088 \\
\hline & $\mathrm{B}$ & 758.6 & 50.2 & 0.294 & 0.509 & 2.541 & 0.013 & (medium) \\
\hline $\mathrm{PM}(\mathrm{kg})$ & G & 3.22 & 0.46 & 0.078 & 0.780 & 2571 & 0.012 & 0.90 \\
\hline & $\mathrm{B}$ & 3.52 & 0.49 & 0.018 & 0.180 & & & (large) \\
\hline MM $(\mathrm{kg})$ & G & 1.14 & 0.15 & 0011 & 0916 & 2559 & 0013 & 0.89 \\
\hline & $\mathrm{B}$ & 1.24 & 0.16 & & & & & (large) \\
\hline
\end{tabular}

Note. G - girl; F - boys; BH - body height; BW - body weight; BMI - body mass index; SMM - skeletal muscle mass; FFM - fat free mass; PBF - percentage of fat mass; WHR - waist to hip ratio; BMR basal metabolic rate, PM - protein mass; MM - mineral mass; $\mathbf{t}$ - value of testing criterion in $t$-test; $p$ - significance; $\eta^{2}$ - effect size 
Table 2. Comparison of obejctivization parameters of physical activity of participants with respect to their gender

\begin{tabular}{|c|c|c|c|c|c|c|c|c|}
\hline \multirow{2}{*}{\multicolumn{2}{|c|}{ Variables }} & \multirow{3}{*}{$\begin{array}{c}\text { Mean } \\
118.3 \\
\end{array}$} & \multirow{3}{*}{$\begin{array}{c}\begin{array}{c}\text { Standard } \\
\text { deviation }\end{array} \\
6.9 \\
\end{array}$} & \multicolumn{2}{|c|}{ Levene's Test for Equality of Variances } & \multicolumn{2}{|c|}{ T-test for Equality of Means } & \multirow{2}{*}{$\eta^{2}$} \\
\hline & & & & $F$ & $\mathrm{p}$ & $\mathrm{t}$ & $\mathrm{p}$ & \\
\hline \multirow{2}{*}{$\mathrm{HR}_{\mathrm{A}}(\mathrm{bpm})$} & G & & & \multirow{2}{*}{0.017} & \multirow{2}{*}{0.896} & \multirow{2}{*}{1.041} & \multirow{2}{*}{0.305} & \multirow{2}{*}{$\begin{array}{c}0.028 \\
\text { (small) }\end{array}$} \\
\hline & B & 120.7 & 7.3 & & & & & \\
\hline \multirow{2}{*}{$\mathrm{HR}_{\mathrm{PA}}(\mathrm{bpm})$} & G & 127.9 & 9.5 & \multirow{2}{*}{0,146} & \multirow{2}{*}{0.704} & \multirow{2}{*}{2.459} & \multirow{2}{*}{0.019} & \multirow{2}{*}{$\begin{array}{c}0.137 \\
\text { (medium) }\end{array}$} \\
\hline & B & 135.4 & 9.6 & & & & & \\
\hline \multirow{2}{*}{$\mathrm{PA}_{\mathrm{s}}(\mathrm{min})$} & G & 23.4 & 10.5 & \multirow{2}{*}{5.467} & \multirow{2}{*}{0.025} & \multirow{2}{*}{2.541} & \multirow{2}{*}{0.015} & \multirow{2}{*}{$\begin{array}{c}0.145 \\
\text { (large) }\end{array}$} \\
\hline & B & 38.7 & 26.3 & & & & & \\
\hline \multirow{2}{*}{$\mathrm{PA}_{\mathrm{H}}(\min )$} & G & 73.8 & 28.9 & \multirow{2}{*}{0.256} & \multirow{2}{*}{0.616} & \multirow{2}{*}{-0.319} & \multirow{2}{*}{0.751} & \multirow{2}{*}{$\begin{array}{c}0.003 \\
\text { (small) }\end{array}$} \\
\hline & B & 70.9 & 27.7 & & & & & \\
\hline \multirow{2}{*}{$\mathrm{PA}_{\text {Sum }}(\mathrm{min})$} & G & 97.2 & 31.7 & \multirow{2}{*}{0.556} & \multirow{2}{*}{0.460} & \multirow{2}{*}{1.156} & \multirow{2}{*}{0.255} & \multirow{2}{*}{$\begin{array}{c}0,034 \\
\text { (small) }\end{array}$} \\
\hline & B & 109.6 & 36.0 & & & & & \\
\hline
\end{tabular}

Note. G - girl; $\mathbf{F}$ - boys; $\mathbf{H R}_{\mathbf{A}}$ - heart rate average; $\mathbf{H R}_{\mathbf{P A}}$ - heart rate during physical activity; $\mathbf{P A}$ - school physical activity; $\mathbf{P A} \mathbf{H}_{\mathbf{H}}$ - home physical acti vity; $\mathbf{P} \mathbf{A}_{\text {sum }}$ - sum of physical activity; $\mathbf{t}$ - value of testing criterion in t-test; $\mathbf{p}$ - significance; $\eta^{2}$ - effect size

Table 3. Analysis of a relationship between physical activity and body composition indicators

\begin{tabular}{|l|c|c|c|c|c|}
\hline Variables & $\begin{array}{c}\mathrm{HR}_{\mathrm{A}} \\
(\mathrm{bpm})\end{array}$ & $\begin{array}{c}\mathrm{HR}_{\mathrm{PA}} \\
(\mathrm{bpm})\end{array}$ & $\begin{array}{c}\mathrm{PA}_{\mathrm{S}} \\
(\mathrm{min})\end{array}$ & $\begin{array}{c}\mathrm{PA}_{\mathrm{H}} \\
(\mathrm{min})\end{array}$ & $\begin{array}{c}\mathrm{PA}_{\text {Sum }} \\
(\mathrm{min})\end{array}$ \\
\hline BH (cm) & -0.056 & -0.131 & 0.203 & 0.105 & -0.132 \\
\hline BW (kg) & -0.077 & -0.026 & 0.078 & 0.067 & -0.093 \\
\hline BMI (kg.m ${ }^{-2}$ ) & 0.008 & 0.031 & 0.000 & 0.023 & 0.002 \\
\hline SMM (kg) & -0.204 & -0.112 & 0.221 & 0.143 & -0.153 \\
\hline FFM (kg) & -0.208 & -0.112 & 0.235 & 0.160 & -0.153 \\
\hline PBF (\%) & 0.194 & 0.073 & -0.285 & -0.201 & -0.074 \\
\hline WHR & -0.285 & -0.213 & 0.526 & 0.307 & -0.182 \\
\hline BMR (kcal) & -0.204 & -0.116 & 0.224 & 0.147 & -0.153 \\
\hline PM (kg) & -0.219 & -0.124 & 0.267 & 0.175 & -0.166 \\
\hline MM (kg) & -0.062 & 0.001 & 0.144 & 0.156 & -0.079 \\
\hline
\end{tabular}

Note. BH - body height; BW - body weight; BMI - body mass index; SMM - skeletal muscle mass; FFM - fat free mass; PBF - percentage of fat mass; WHR - waist to hip ratio; BMR basal metabolic rate, PM - protein mass; $\mathbf{M M}$ - mineral mass; $\mathbf{H R}_{\mathrm{A}}$ - heart rate average; $\mathbf{H R}_{\mathbf{P A}}$ - heart rate during physical activity; $\mathbf{P} \mathbf{A}_{\mathbf{S}}$ - school physical activity; $\mathbf{P} \mathbf{A}_{\mathbf{H}}$ - home physical activity; $\mathbf{P} \mathbf{A}_{\text {Sum }}-$ sum of physical activity; $* \mathrm{p}<0.05$ 


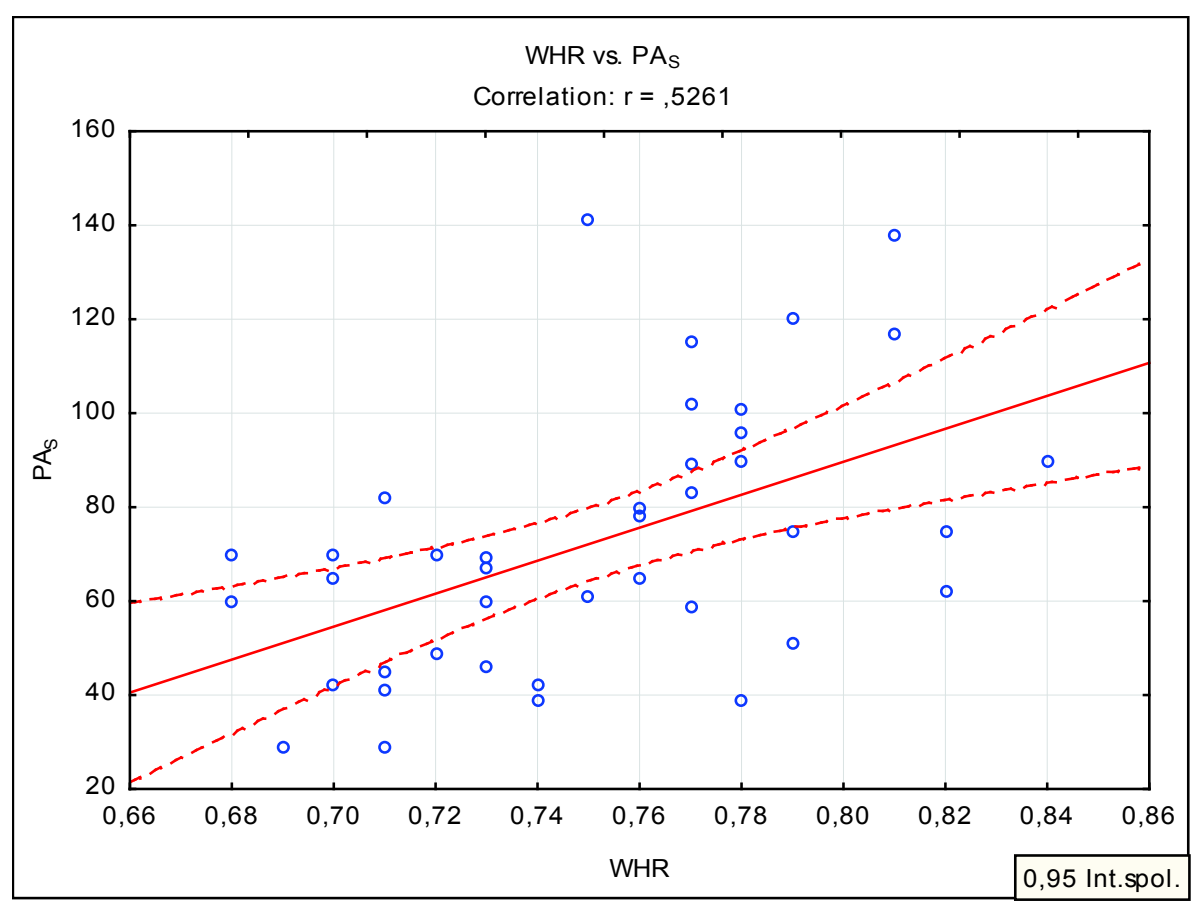

Figure 1. Anlysis of relationship betwen parameters waist to hip ratio and physical activity at kindergarden Note. WHR - waist to hip ratio; $\mathbf{P A}_{\mathrm{s}}$ - school physical activity

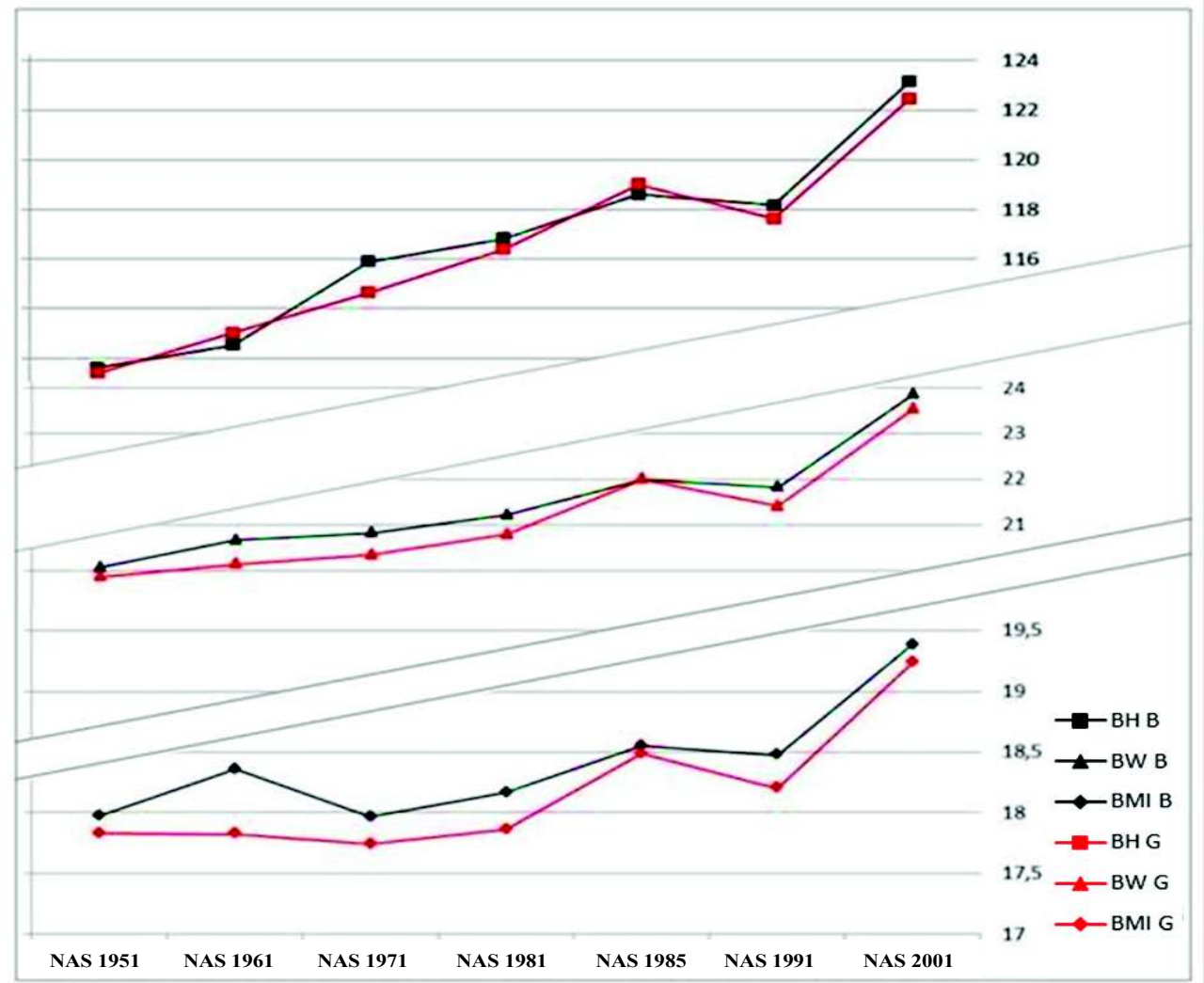

Figure 2. National anthropometric measurements

Note. BH- body height, BW- body weight, B- boys, G- girls, BMI- body mass index, NAS- national anthropometric survey 


\section{PA}

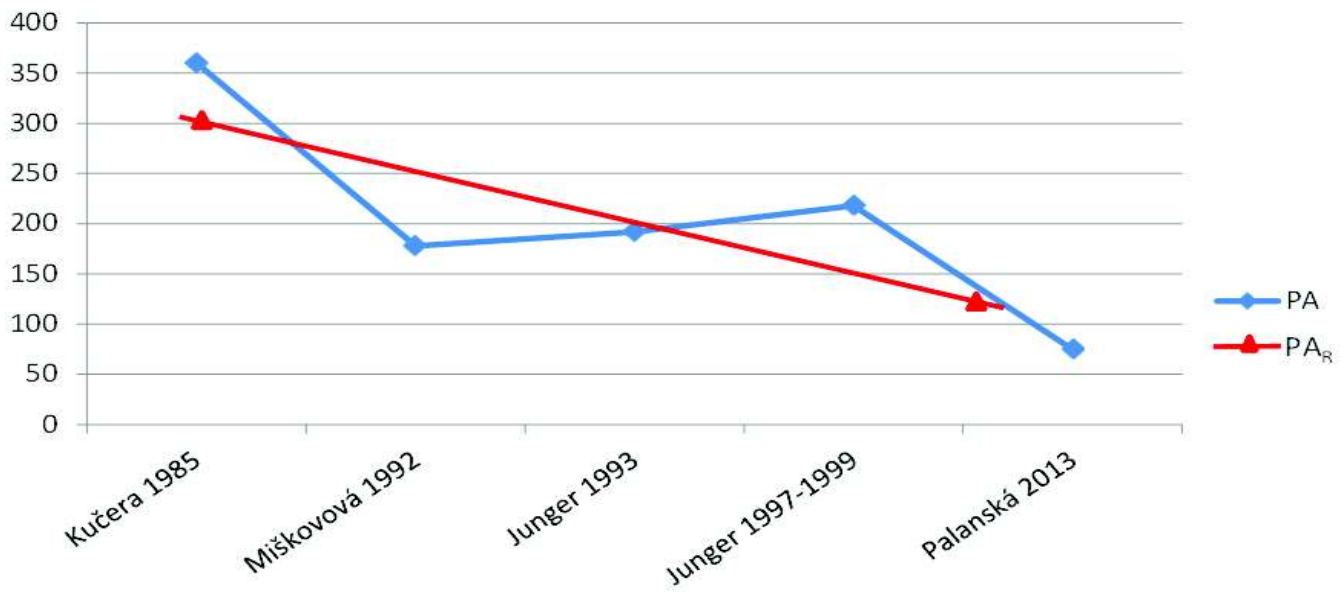

Figure 3. Physical activity of preschool children (daily average/min)

Note. PA- physical activity, $\mathbf{P A}_{\mathbf{R}}$ - recommended physical activity according to Calzozari et al. (1985) - NASPE (2002)

\section{Conclusions}

1. Somatic development of the children studied corresponds with the secular trend confirmed by higher means for body height and body weight.

2. The analysis of body composition data has confirmed our personal experience in that somatic development of preschool children is still determined predominantly by endogenous factors and not by difference in their lifestyles.

3. Measures of somatic development are disproportionate to physical activity levels of children, which is regarded as an irreplaceable factor underlying their healthy development. However, physical activity level of children is gradually decreasing.

4. The volume of daily physical activity does not meet the minimum standard recommended by NASPE and average intensity of physical activity expressed by heart rate does not reach the medium intensity zone.

5. Average heart rate monitored during entire stay in the kindergarten is $20 \mathrm{bpm}$ higher than resting heart rate of children.

\section{References:}

1. Béderová A. (2003), Príloha o racionálnej výžive v škole a rodine. Prevencia a učitelia. Rodina a škola. 1: 29.

2. Bláha P. et al. (1990), Antropometrie českých předškolních dětí ve věku od 3 do 7 let. Praha Ústav sportovní medicíny

3. Bláha P., Vignerová J. (1998), Vývoj tělesných paramtrů českých deti a mládeže se zaměřením na rozměry hlavy. Praha Univerzita Karlova.

4. Canning PM., Courage ML., Frizzell LM. (2004) Prevalence of overweight and obesity in a provincial population of Canadian preschool children. Canadian Medical Association Journal; 171: 240-242.

5. Cohen J. (1988), Statistical power analysis for the behavioral sciences. 2nd ed. Hillsdale (NJ) Lawrence Erlbaum Associates.

6. Corbin CB., Pangrazi RP. (1996), How much physical activity is enough? J. Phys. Educ. Recr. Dance.; $4: 33$ - 37.

7. Frömel K., Novosad J., Svozil Z. (1999), Pohybová aktivita a sportovní zájmy mládeže. Olomouc Univerzita Palackého.

8. Hainer V et al. (2004), Základy klinické obezitologie. 1st ed. Praha Grada Publishing.

9. Jakicic JM., Otto AD., Polzien K., Davis K. (2009), Physical activity and weight control. Oxford University Press (NY).

10. Junger J. (2010), Štátny vzdelávací program pre predprimárne vzdelávanie ISCED 0 v reflexii motorického rozvoja diet'at'a. Perceptuálno-motorické učenie sa v predprimárnej edukácii v kontexte súčasnej kurikulárnej; 1: 391.

11. Junger J. (2000), Telesný a pohybový rozvoj detí predškolského veku. Prešov Grafotlač.

12. Kraut A., Melamed S., Gofer D., Froom P. (2003), Effect of school age sports on leisure time physical activity in adults: The CORDIS study. Medicine and Science in Sports and Exercise.; 35(12): 2038-2042. 
13. Kučera M. (1985), Kvalitatívni a kvantitatívni změny bipedální lokomoce v průběhu vývoje. Praha Univerzita Karlova.

14. Kučera M. (1991), Tělesná zátěže při školním vyučovaní. Těl. Vých. Mlád.; 7-8: 198.

15. Kyle UG., Bosaeus I., De Lorenzo AD., Deurenberg P., Elia M., Gomez JM., Pichard, C. (2004), Bioelectrical impedance analysis principles and methods. Clinical Nutrition.; 23(5): 1226-1243.

16. LaMonte M., Blair SN. (2009), Physical activity, fitness, and delayed mortality. Oxford University Press (NY).

17. Malina RM., Bouchard C., Bar-Or O. (2004), Growth, maturation, and physical activity. Champaign (IL) Human Kinetics.

18. Marinov Z. et al. (2012), Praktická dětská obezitologie. 1st ed. Praha Grada Publishing.

19. National association for sport and physical education (NASPE). Active Start: A Statement of Physical Activity Guidelines for Children Birth to Five Years. Available at: http://journal.naeyc.org/btj/200605/NASPEGuidelinesBTJ.pdf (access: 21.5.2015).

20. Pangrazi RP., Corbin CB., Welk GJ. (1996), Physical activity for children and youth. J. Phys. Educ. Recr. Dance.; 4: $38-43$.

21. Prokopec M. et al. (1986), Výška a hmotnost českých dětí v roce 1981 podle výsledkủ celostátního antropologického výskumu. Čs. Pediater.; 41(1): 20-26.

22. Sigmund E., Sigmundová D. (2011), Pohybová aktivita pro podporu zdraví dětí a mládeže. Olomouc Univerzita Palackého.

23. Tucker P. (2008) The physical activity levels of preschool-aged children: A systematic review. Early Childhood Research Quarterly:; 23: 547-558.

24. World Health Organization. Childhood overweight and Obesity. Available at: http://www.who.int/dietphysicalactivity/childhood/en/ (access: 21.5.2015).

25. World Health Organization. Noncommunicable diseases country profiles 2011. Geneve World Health Organization, 2011.

Submitted: 25.08.2014

Accepted: 19.09.2014 